\title{
Analysis on the Agricultural Trade between China and Countries along "One Belt, One Road"
}

\author{
Xiujuan Wang1,2, Yuee $\mathrm{Li}^{1,2}$, Jilian $\mathrm{Hu}^{2 *}$ \\ ${ }^{1}$ Foreign Languages Colleges, Shandong Agricultural University, Taian, China \\ ${ }^{2}$ School of Economics and Management, Shandong Agricultural University, Taian, China \\ Email: xjw9007@126.com, *jlhu@sdau.edu.cn
}

How to cite this paper: Wang, X.J., Li, Y. and Hu, J.L. (2018) Analysis on the Agricultural Trade between China and Countries along "One Belt, One Road". Modern Economy, 9, 1977-1986.

https://doi.org/10.4236/me.2018.912123

Received: August 15, 2018

Accepted: December 1, 2018

Published: December 4, 2018

Copyright $\odot 2018$ by authors and Scientific Research Publishing Inc. This work is licensed under the Creative Commons Attribution International License (CC BY 4.0).

http://creativecommons.org/licenses/by/4.0/

(c) (i) Open Access

\begin{abstract}
The proposal of "One Belt And One Road" provides a favorable opportunity for development of China's agricultural products trade. By applying literature research method, information processing method, inductive method and other methods, this paper analyzes the agricultural trade between China and countries along the "One Belt, One Road" route, states the present situation and characteristics of agricultural trade between China and countries along the "One Belt, One Road" route and puts forward the main problems existing in the process of trade, and then researches the idea and path of agriculture opening and economic and trade cooperation further between China and countries along the "One Belt, One Road" route. The result shows that competitiveness and complementation of agricultural trade between China and countries along the "One Belt, One Road" route are all exist. China and countries along the "One Belt, One Road" route should strengthen agricultural trade cooperation and enrich the connotation of agricultural cooperation on the basis of existing multilateral mechanisms, thus realizing mutual benefit and development.
\end{abstract}

\section{Keywords}

Countries along the "One Belt, One Road" Route, Agricultural Trade, Current Situation of Trade, Problems, Countermeasures

\section{Introduction}

\subsection{Research Background}

In 2013, chairman Xi successively put forward the strategy of "silk road economic belt" and "Marine silk road in the 21st century". In March 2015, "the drive of economic belt of Silk Road and the vision and action of the maritime ${ }^{\star}$ Corresponding author. 
Silk Road in the 21st century" officially launched. "One Belt, One Road" is a cooperative development ideas and initiatives, which shows that China's determination to further opening. Agricultural products trade and economic cooperation is an important part of the strategy of "One Belt, One Road". Throughout the development history of "Silk Road", trade of agricultural products and agricultural foreign exchange has been the main content of the ancient Land and Sea Silk Road. China is famous for its tea, silk and other agricultural products too. With the development of social economy or agricultural technology and continued deepening of world trading cooperation, agricultural economic cooperation and trade exchanges between China and countries along the "One Belt, One Road" route present new characteristics and development tendency [1] [2]. The proposal and implementation of "One Belt, One Road" strategy provide a rare historical opportunity for the development of our country's agricultural product trade. These indicate that China's opening to the outside world is from opening to coastal cities to opening to all and China's foreign economic cooperation partners and from focusing on developed economies to focusing on neighboring countries and developing countries [3]. All in all, the implementation of the "One Belt, One Road" strategy has a huge potential benefit but also faces great difficulties and risks.

\subsection{Purpose and Significance of the Research}

China is a large country with a population of 1.4 billion and agriculture maintains the important responsibility of the people's livelihood and national economic base [4]. With the gradually expanding of open-door to the outside world, not only the value of agricultural production of our country increases quickly, but also the change of industrial structure are significant. Therefore, under the background of strategy implementation of "One Belt, One Road", researching new characteristic and new tendency showing in the process of Agricultural economic and trade exchanges and cooperation between China and countries along the "One Belt, One Road" route; researching that which product has the potential for cooperation or which product has competition between China and countries along the "One Belt, One Road" route; researching how to grasp the opportunity for agriculture under the strategy of "One Belt, One Road" to make full use of "two resources and two markets" at home or abroad and combine "going out" with "introducing"; researching how to realize win-win cooperation by strengthen the agricultural economic and trade cooperation China and countries along the "One Belt, One Road" route and so on [5]. These are all realistic problems the strategy of "One Belt, One Road" advocating to solve.

"Silk Road Economic Belt" and "the 21st Century Maritime Silk Road" are great actions to expand and deepen the policy of "opening to the outside world" and carries out a more proactive opening-up strategy in the new period of our country. And these two tactics receive wide attention and recognition by the international community [6]. Countries along the "One Belt, One Road" route 
have a long agricultural civilization and rich in agriculture, forestry, fishing and market resources, occupying a important position in world agriculture. These countries are the focus of the China's agricultural products trade and foreign agricultural cooperation. With speeding up globalization of economy and the pace of opening to the outside world, the trade relationship between China and countries along the "One Belt, One Road" route become closer gradually [7]. Trade scale expands unceasingly, trading speed accelerates quickly and trade has a great potential. This article selects agricultural trade between China and countries along the "One Belt, One Road" route to analyze, which adapts to the current trend of the Times and China's foreign trade status. We believe that this paper is of great significance for analyzing the problem of global trade.

\subsection{Research Method}

\subsubsection{Literature Research Method}

Through consulting the relevant books in the library and knowing the predecessors' research progress in this subject by using China National Knowledge Internet and VIP database, I can acquire effective information about this topic. In addition, I search on the internet in order to practical official data. Finally, I use the method of combining the first-hand material with second-hand data to form a writing outline.

\subsubsection{Information Processing Method}

At present, we are in a new era of "information revolution" and there are a lot of information resources to develop and utilize. In order to understand the condition of agricultural trade between China and countries along the "One Belt, One Road" route, we use the network and library to carry out data collection, transmission, processing and finishing, and then applying these data to the practice. This provides powerful gist of solving problems and putting forward suggestions.

\subsubsection{Inductive Method}

By summarizing and concluding text information and data collected about agricultural trade between China and countries along the "One Belt, One Road" route, I form integral and regular cognition about this topic. On the side, on the basis of summarizing and concluding these data, I make an analysis integrally of agricultural trade.

\section{Present Situation Analysis and Main Problems}

\subsection{Rising Total Volume of Trade}

The import and export amount of agricultural product between China and countries along the "One Belt, One Road" route has some volatility to some extent, but as a whole tends to rising trend. The total value trade of agricultural product between China and countries along the "One Belt, One Road" route increases quickly from 1995 to 2015: there are 59 billions of dollars in 1995 while 
there are 621 billions of dollars in 2015, which shows the total volume of trade changes dramatically. The trade of agricultural product between China and countries along the "One Belt, One Road" route appeared rapid development for the first time in 2001. However, it decreased apparently in 2008 because of financial crisis. With formal effectiveness of China-Asean free trade zone, the trade of agricultural product between China and countries along the "One Belt, One Road" route appeared rapid development for the second time and the growth rate improved significantly. In 2012, financial crisis occurred again, which resulted that agricultural trade contacts decreased. But growth was restored after a short while. In an overall view, ignoring the impact of the financial crisis, the growth trend of agricultural trade between China and countries along the "One Belt, One Road" route is stable and apparent.

\subsection{Higher Market Concentration}

These 64 countries along "One Belt, One Road" route which trade agricultural product with China have obvious characteristic of market concentration. For example, in terms of export of Chinese agricultural product, the market concentration is high; and in terms of import of Chinese agricultural product, the market concentration is higher, because more than $98 \%$ agricultural products importing from countries along the "One Belt, One Road" route are from the top 15 countries. At the same time, China has been in deficit in the agricultural products trade with these countries along the "One Route, One Road" route and the trade deficit shows a trend of decreasing firstly then increasing after. Chinese exports of agricultural products to these countries along the "One Route, One Road" route grows continually comparing with total exports of agricultural products, which states agricultural trade between China and countries along the "One Belt, One Road" route is more and more important.

\subsection{Limited Trading Partners}

The main partners are Southeast Asian countries in the process of agricultural products trading between China and countries along the "One Belt, One Road" route. And in Southeast Asian countries, China trades with Indonesia, Malaysia, Thailand and Vietnam more closely. Southeast Asian countries are main partners of countries along the "One Belt, One Road" route, which carry out agricultural trade with China: there are six ASEAN countries of ten that import agricultural products in 2010, and their total trade volume accounts for $50.76 \%$ of China's total trade volume. Although there are only five ASEAN countries of ten that import agricultural products in 2015, their total trade volume accounts for $54.9 \%$ of China's total trade volume (China Statistics Yearbook 2015). This conclusion illustrates that agricultural trade between China and Central Asian countries or Ring of central Asia remains to be further improved. As China's neighbors, not only the transportation of South-east Asian countries is convenient but also they are the foreign priorities, which is advantageous to the de- 
velopment of bilateral trade. For another, effect of China-Asian free trade area greatly strengthened the trade links between southeast Asian countries and our country. Therefore, we should be strengthen cultural exchanges and economic and trade exchange between China and Asian countries or Ring of central Asia appropriately, in order to open the trade market between China and such countries along the "One Belt, One Road" route.

\subsection{Agricultural Trade Concentrates on Limited Varieties}

Agricultural trade between China and countries along the "One Belt, One Road" route concentrates on a few varieties. China's exports to countries along the "One Belt, One Road" route focus on labor-intensive products and capital-intensive products, and its main importing products are crops. Because agricultural trade between China and countries along the "One Belt, One Road" route are mainly in Central Asia Ring of central Asia and southeast Asian countries. Land resources in Central Asia and Ring of central Asia are very rich, which results that food crops such as land intensive agricultural products in these areas has a strong export advantage on foreign trade development. Southeast Asian countries belong to tropical monsoon climate and tropical rainforest climate, and rainy all year around, so the aquatic animals, fruits and vegetables have strong export advantage. China's agricultural products mainly imported from countries along the "One Belt, One Road" route are animal and plant oil, cotton and vegetables to eat, while its agricultural products mainly exported are edible vegetables, edible fruit and nut products. Therefore, we need to further expand trade varieties and types, expand the scale of trade development, and reduce the risk of market and product concentration.

\subsection{Main Problems}

\subsubsection{Relatively Small Trading Amount of Agricultural Product}

Agricultural trade between most countries along the "One Belt, One Road" route and China is inactive, and the trading amounts are small. Statistics indicate that most countries' amount of agricultural products imported from China is very large. Meanwhile, export data also shows the same characteristic. At present, Benefiting from the neighbors and China-Asean free trade area cooperation mechanism, our country makes agricultural product trade with Southeast Asian countries closely. However, agricultural products trade between South Asia or central and eastern European countries accounts for only a few. In consequence, under existing economic and trade cooperation mechanism, our country should strengthen and promote agricultural trade cooperation with countries along the "One Belt, One Road" route especially South Asian countries and eastern European countries.

\subsubsection{Relative Higher Cost of Trading}

Trade costs directly affect the comparative advantage of a country's goods in the international market, transportation costs, trade scale and trade barriers are all 
important factors to determine the costs of trade. According to statistics settled by World Bank, only 19 of countries along the "One Belt, One Road" road scores in 3 or more about their infrastructure, and these countries concentrates in Southeast Asia, West Asia, central and eastern Europe. Look from the trade scale, expect for the association of southeast Asian nations, total volume of trading with China is relative small. There are lots of trade barriers exiting in the agricultural trade between China and these countries. For example, Central Asia import and export formalities of Central Asia countries are fussy, and time of duration to complete the export formalities is relative longer. Moreover, many developing countries along the "One Belt, One Road" route have fragile financial system and the volatile exchange rate. In conclusion, these are all important factors that lead to the high cost of trade between China and countries along the "One Belt, One Road" route.

\subsubsection{Serious Regional Trade Protection}

Many countries along the "One Belt, One Road" route are developing countries which are in the period of transition of social and economic structure. Regional trade protection in these countries is serious. Take India for an example, India is an important pivot point of "One Belt, One Road", but it launches lots of anti-dumping lawsuits in our country. From 1994 to 2013, Indian anti-dumping cases against China increases year by year with an average annual growth rate of about $11 \%$. In addition, marketing environment needs to improved, legal system is not sound and trading investment protection is not sufficient, which result that violation of international practice and commercial fraud often happen. Moreover, there are many uncertainties in both security and development especially in the Middle East, Central Asia and South Asia. Some countries' political situation is volatile, terrorist attacks and the war on terror happen frequently, and infrastructure assets are easy to investment but difficult to keep. So threats and challenges influence economic and trade cooperation seriously.

\subsection{4. "Power Politics" Influences the Regional Economic and Trade Cooperation}

China is bordered with India and Russia and they are all big countries pursuing economic development. They pursue common interests in economic cooperation but there is a strong competition on the geopolitical relations. India never gives positive response to the stratagem of "One Belt, One Road". Because India worries that China is likely to become a maritime power if China's maritime Silk Road project could be implemented. Under such a background, Moody government launched their own Silk Road project in June 2014 "across the Indian Ocean sea route and the cultural landscape plan". The aim of this plan is to build the Indian Ocean world with Indian Ocean countries, in order to expand and strengthen India's influence in the Indian Ocean region. At the same time, Russia launched the "north-south corridor plan" in 2010. And in recent years, Russia propels Eurasian union mainly to continue to strengthen its control and influence of the commonwealth of independent state. Russia considers central Asia 
as its traditional sphere of influence and is suspicious of other powers into the region. Besides, the United States announced plans to implement the strategy of "Asia Pacific rebalance" in 2012, in order to improve Asia's position in American economic and trade. The Unite States indulge that Japan and Philippines provoke the dispute of Diaoyu islands and the South China sea. These disputes are difficult to solve in the short term, which will prevent all-round cooperation between China and Asean countries.

\section{Countermeasures and Prospects}

\subsection{Enhancing the Level of Economic and Trade Cooperation}

At present, total trade of our country along with the bilateral agricultural products takes a small proportion of total export trade of agricultural products, indicated that improve the scale of the bilateral agricultural trade is the most important mission. Under the regional cooperation framework advocated by the "One Belt, One Road", we should adhere to the principle of mutually beneficial cooperation, actively promote the establishment of a free trade area, and gradually built a high level network of free trade zone. At the same time, we should establish fair, safe and stable regional agricultural market system, eliminate the tariff barriers and non-tariff barriers, and improve the size of bilateral agricultural products trade.

\subsection{Reducing Trade Cost}

Since 2013, China's global trade in goods import and export is among the world first. However, cumbersome procedures and complex trade system has become a bottleneck restricting the development of China's trade. The government should take necessary measures to simplify the process of trade management, and provide convenient channel for the customs declaration, customs clearance, inspection and quarantine of import and export enterprises, which can greatly improve the trade efficiency and reduce cost. At this point, the unity of the European countries to establish a customs declaration system has important significance. In addition, we should strengthen the infrastructure interconnectivity together with the country along the route, improve transport efficiency, and reduce logistics cost. The difference between the historical "silk road" and current "One Belt, One Road" is that the former is the line for the "trade route", whereas the latter is based on a linear "trade route" for industrial and population concentration, which promote the surrounding areas to become "economic belt". Up to now, the infrastructure interconnectivity and cooperation framework between the countries along the "One Belt, One Road" route are far from complete. The tasks getting through the traffic and logistics can not be completed in one day or with one country's strength, and it need to participate and cooperate with each countries.

\subsection{Reasonable Scientific Planning}

We should pay more attention to and strengthen the national agricultural coop- 
eration with complementary advantages in our country, especially in South Asia and central and eastern European countries and regions, and focus on choice of grain, cotton, rubber and cork with complementary structure and comprehensive benefit of good varieties, and excellent industry such as crop processing, agricultural products logistics and ecological protection in our country. Meanwhile, we should use the cooperation ways such as aid, investment and technology transfer effectively, and through multilateral or bilateral level to establish a long-term mechanism. In addition, short-term, medium-term and long-term planning should be developed and implemented step by step, which can guide the adjustment of agricultural and trade structure at the basis of increasing international competitiveness of our country's agricultural products.

\subsection{Setting up the Sample Countries}

As previously mentioned, there are many countries along the "One Belt, One Road" route and they have different development levels and different ideas. Some of them made a positive response to the "One Belt, One Road" strategy, while others hold either wait-and-see attitude or skepticism, such as "China threat theory", "Chinese expansion theory" and so on false statements. In this case, rather than promoting "One Belt, One Road" strategy, we should select priority countries as the example of economic and trade cooperation in all the regions, build a batch of fully open regional cooperation and maritime strategic fulcrum in the hallway. Take central Asia for example, Kazakhstan, a biggest economies in central Asia and of the China's largest trading partner in central Asia, takes a positive response to the "One Belt, One Road" strategy and lists China silk road economic belt as one of the "the top 10 of the most important events in Central Asia in 2015", and actively seeks the silk road economic belt effective docking with the domestic economic strategy. So, we can priority to choose Kazakhstan as the key point for cooperation with Central Asia, intensify the strength of trade and investment with Kazakhstan and strive for an early result, which will become a cooperation mode as for promoting cooperation with other countries. And so on, comprehensively inspecting economic development level, degree of openness to trade, political system stability and other factors of surrounding countries, we should choose Singapore, Indonesia, Malaysia and other countries as key partners in southeast Asia regions, choose India and Pakistan in South Asia, choose Russia in the commonwealth of independent states region, choose Saudi Arabia and Turkey in the West Asia area, choose Poland and the Czech republic in central and eastern Europe area when advances the strategy of "One Belt, One Road".

\subsection{Enriching the Connotation of Cooperation}

For the external aspects, based on the current cooperative mechanism and established friendly political relations with the countries along the "One Belt, One Road" route, we should further build pragmatic platform of agricultural cooper- 
ation. In view of the agriculture issues or a particular aspect that every country concerns, the new multilateral or bilateral cooperation mechanisms should be built. For the internal aspects, we should strengthen the support to the enterprises related to the strategy of "One Belt, One Road", including the support to agricultural enterprises of foreign trade and investment, such as loan guarantees, interest rate subsidies, technical support, and the timely follow up supporting policies.

\subsection{Risks Prevention}

With frequent trade and further open markets, agricultural enterprises and related organizations encountered many problems on the road of "going out", such as being unfamiliar to national or regional industry rules and religious cultures. So we need to strengthen the propaganda of "going out" enterprise training and education, abide by the local customs when do business, and establish a good image of the Chinese agriculture. On the other hand, we should make the enterprise management order normative and implement access and exit mechanisms to the agricultural "go out" and "introduction to" strategies. The aim is to avoid rush and vicious competition. While the enterprises develop foreign market, they should make full use of technology and other resources at home and abroad, comprehensively enhance product competitiveness, at the same time prevent trade friction and deal with the challenge, which will better adapt to the internationalization and integration of the trend.

\section{Conclusions}

Through analyzing trade structure between China and countries along the "One Belt, One Road" route, we can find that "One Belt, One Road" intra-regional trade is growing rapidly and the industry between countries is in a different gradient. Trade complementarity is significantly higher than the competitive between countries and there are good trade prospects for cooperation. But there are also barriers such as high trade cost, serious trade protection and geopolitical game influencing agricultural trade between big countries. In order to better achieve the goal of intra-regional trade's opening all the way: firstly, we should choose to cooperate with key countries so as to give play to existing industry comparative advantage of our country; secondly, it is necessary for China to establish a reasonable trade industrial chain; last but not least, Our country should decrease the cost of foreign trade by strengthening the construction of infrastructure and the interconnectivity of policy areas.

As we can see, countries along the "One Belt, One Road" route play an important role in the trade of agricultural products and agricultural development with our country. In consequence, our country should insist on the ancient Silk Road's spirit of open tolerance, mutual benefit and win-win design. China should actively promote agricultural products trade and agricultural cooperation between China and countries along the "One Belt, One Road" route, in order to 
achieve mutual benefit and common development.

\section{Acknowledgements}

This paper is supported by Social Science Project of Shandong Agricultural University (No. 23899), Humanities and social science research project in Shandong province (No. J16WC49); Teaching and Reform Project of Shandong Agricultural University(X2017093).

This paper is one of the author's research outcomes as academic visitor in Lancaster University in UK from 1 September, 2018 to 1 March in 2019.

\section{Conflicts of Interest}

The authors declare no conflicts of interest regarding the publication of this paper.

\section{References}

[1] Alameddine, M. and Abdel-Salam, S. (2011) Stakeholders' Perspectives on the Regulation and Integration of Complementary and Alternative Medicine Products in Lebanon: A Qualitative Study. BMC Complementary and Alternative Medicine, 11, 71.

[2] Bryson, J.M., Patton, M.Q. and Bowman, R.A. (2011) Working with Evaluation Stakeholders: A Rationale, Step-Wise Approach and Toolkit. Evaluation and Program Planning, 34, 1-12. https://doi.org/10.1016/j.evalprogplan.2010.07.001

[3] Caniato, M. and Vaccari, M. (2014) Using Social Network and Stakeholder Analysis to Help Evaluate Infectious Waste Management: A Step towards a Holistic Assessment. Waste Management, 34, 938-951. https://doi.org/10.1016/j.wasman.2014.02.011

[4] Copeland, B.R. and Taylor, M.S. (1994) North-South Trade and the Environment. The Quarterly Journal of Economics, 109, 755-787. https://doi.org/10.2307/2118421

[5] De Stefano, L. (2010) Facing the Water Framework Directive Challenges: A Baseline of Stakeholder Participation in the European Union. Journal of Environmental Management, 91, 1332-1340. https://doi.org/10.1016/j.jenvman.2010.02.014

[6] Jia, L. (2016) Opportunities and Challenges Faced by Xinjiang Enterprises in the Marketing under the Strategy Background of One Belt One Road. ESSAEME, 71, 41-45.

[7] Wang, P.Z. and Xu, S.X. (2016) The Strategy Study of Agricultural Trade between China and Five Countries in Central Asia under the Context of "One Belt, One Road". AETMS, 11, 302-306. 